\title{
Students' Difficulties in the Practice of Volleyball in School Physical Education: An Analysis Based on Tactical Principles
}

\author{
Chanh Thuc Dao ${ }^{1, *}$, Van Tang Nguyen ${ }^{2}$ \\ ${ }^{1}$ Department of Physical Education, An Giang University, Vietnam National University, Ho Chi Minh City, Vietnam \\ ${ }^{2}$ Department of Athletics, Ho Chi Minh University of Sport, Ho Chi Minh City, Vietnam
}

Received November 28, 2020; Revised December 28, 2020; Accepted January 28, 2021

\section{Cite This Paper in the following Citation Styles}

(a): [1] Chanh Thuc Dao, Van Tang Nguyen, "Students' Difficulties in the Practice of Volleyball in School Physical Education: An Analysis Based on Tactical Principles," International Journal of Human Movement and Sports Sciences, Vol. 9, No. 1, pp. 41-47, 2021. DOI: 10.13189/saj.2021.090106.

(b): Chanh Thuc Dao, Van Tang Nguyen (2021). Students' Difficulties in the Practice of Volleyball in School Physical Education: An Analysis Based on Tactical Principles. International Journal of Human Movement and Sports Sciences, 9(1), 41-47. DOI: 10.13189/saj.2021.090106.

Copyright $(2021$ by authors, all rights reserved. Authors agree that this article remains permanently open access under the terms of the Creative Commons Attribution License 4.0 International License

\begin{abstract}
In Vietnam, physical education is mostly still taught in a traditional model. Volleyball is one of the most practiced sports in Physical Education classes. The study of this article was to explore students' difficulties in the practice of volleyball in school Physical Education (PE) classes, according to the tactical principles of the sport, and to compare them with teachers' understanding of the discipline. This qualitative study was developed in two stages: a) observation of 14 hours/class PE volleyball classes in two different schools and field diary records of students' difficulties during the game according to the tactical principles of the sport, and b) application of a Linkert scale with active PE teachers to classify such problems (Thomás A.P, et al 2020). In the first stage, the following situations were identified as difficulties, in decreasing order of occurrence in the observations: building the attack, occupying spaces on the court, looking for empty spaces, intending to contact the ball, and directing serves. In the teachers' view, however, difficulties in serves were indicated as students' main problem and, on the other hand, occupying court spaces as the action they performed more easily. On this basis, it is concluded that there are differences between the researcher's and the teachers' views, possibly related to teachers' initial coaching and previous experiences based on the traditional model, whose focus is not on the teaching of tactical principles.
\end{abstract}

Keywords Volleyball, Sports Exploration, Internal Logic, Sport Pedagogy, Students' Difficulties

\section{Introduction}

Volleyball is one of the most practiced sports by the Vietnamese population in several spaces, including schools, through Physical Education classes (Thuc D.C et al., 2018).

Regarding volleyball in Vietnamese PE, the sport is one of the most discussed contents in classes, from the sports model to the most recent perspectives in the area, such as Corporal Culture (Thuc D.C et al., 2018). However, it is observed that the traditional teaching model is the predominating one since the emphasis is on teaching the fundamentals of volleyball, such as overhead and forearm pass, and spike (Barroso \& Darido, 2010), as confirmed by recent studies about volleyball, which present analyses of the practice based on these fundamentals and their effectiveness (Alnedral et al., 2020). Knowing how to perform the technical gestures of volleyball is extremely important, however, it is understood that limiting teaching in PE to only this dimension of practice is not indicated (Sgrò et al., 2020). Moreover, according to Borges, Gaya, González, and Galatti (2017), students' main difficulty is 
marked by understanding what actions need to be carried out during the game, which points to the internal logic and tactical principles of the sport, the focus of this study and which completely escapes the traditional teaching proposal for sports in general.

To work with tactical principles and overcome the traditional model of volleyball teaching, considered by many as an excluding practice (Lima et al., 2012), decontextualized from the game (Hirama et al., 2015), it is understood that, in the quest to solve students' difficulties, current approaches of Sport Pedagogy are more appropriate (Parente, 2020).

What places sports modalities within the same logic are the main objectives of the practice (Belli et al., 2017) - in the case of volleyball, sending the ball over the net to the other side to hinder the opponents' actions so that they do not manage or difficulty to complete the action (González \& Bracht, 2012). This goal is common for modalities that fall into the category of net wall sports (Siedentop, 1994). However, teachers do not work with the tactical component in classes, although they recognize the importance of how games work (Fensterseifer et al., 2015).

To promote teaching through the internal logic of the sport in PE classes, first, we need to identify the tactical problems faced by students as difficulties in the game, in a diagnostic process. The knowledge is fundamental for selecting contents to be worked on in class, as they are directly related to the main teaching agent - the student (Borges, Gaya, et al., 2017). Sport explorations, according to Borges, Gaya, et al. (2017), are divided into three main moments: identification of problems, prioritization, and selection, of which two will be used in this study in diagnosing students' difficulties: identification and prioritization. Thus, the objective of this study was to explore students' difficulties in volleyball practice in PE classes, according to the tactical principles of the sport, and to compare findings with teachers' understanding of the discipline.

Such approaches use games (Aquino et al., 2017) prepared following the tactical principles of each modality (Harvey et al., 2020) so that students can understand "what" should be done throughout the game and "when" to take actions (Daólio, 2002), and approaches that use these tools can contribute to the development of volleyball skills (Backman \& Barker, 2020).

\section{Organize the Materials and Methods}

\section{Study Design}

To achieve the study objective, a "mixed" qualitative-quantitative methodology combining the two study methods was selected. Mixed study methods hardly take on an equal share of qualitative and quantitative practices, with the predominance of one of these methods (Thomas et al., 2012; Thomás A.P, et al 2020), in this case, the qualitative aspect, despite the use of quantitative instruments in some stages, as described below.

Qualitative study in Physical Education is organized from the interaction between researcher's and researched to assign meanings to the studied theme, to produce the data required for study, within a context in focus (Smith \& Caddick, 2012). In this case, focused on PE, qualitative study seeks the interaction between researcher, students, and teachers, with a pedagogical approach to practices (Silva et al., 2008).

Accordingly, two steps were taken: (1) observation of volleyball lessons in PE; and (2) application of a questionnaire with PE teachers who worked with volleyball in the final years of elementary and high school.

This type of descriptive study involves the use of observations about a reality and questionnaire administrations to identify elements of the researched context (Thomas et al., 2012).

Both stages are part of the proposal to systematize the contents of sports modalities pointed out by González and Bracht (2012), who indicate making a diagnosis of the problems - stage (Class observation) - and later, a classification of them - Stage (Classification of tactical problems).

Characterizing the schools where the observation was realized, both have a tradition in the city of this study, one private and the other public. Given the difficulty in receiving authorization from schools to observe classes and the difficulty in reconciling the hours of the researcher with the teachers, we opted for these two schools to understand those different realities. The intention was not to compare both realities and either to generalize the results. The frequency of appearance of the behaviors analyzed in the classes is one of the factors that determine the number of observations to be made (Thomas et al., 2012), which justifies the number of 14 hours/class observed, since, without a pre-determination, we got to that amount from the repetition of the actions that occurred during the volleyball games.

\section{Participants}

This stage of the study was carried out in two schools one private (school 1) and the other public (school 2) - in the Long Xuyen city, of An Giang province, Vietnam. To choose the schools, the researchers tried to cover two different educational perspectives to portray in this study. There were 14 hours/class PE classes whose theme was volleyball were observed. Of these classes, eight hours/class of 45-minute (school 1) and the others were doubles - two 50-minute classes, that is, 6 hours/class (school 2). Both observations ("in loco") were carried out in high school because it is expected that students in the 
final school years have already gained some experience with the modality in the previous teaching cycles.

About groups, 1st and 2nd-grade high school students were observed. In school 1, the students chose which sport they want to do in PE classes, bringing together students from both years mentioned, the different situation from most Vietnamese schools, so, those who chose to take volleyball classes were observed. In school 2, with regular Physical Education classes, classes of a 1st-grade group were observed. The groups observed were composed of adolescents, boys and girls, aged between 14 and 16 years old.

Regarding the teaching methodology used in volleyball classes, there was a difference between the two schools observed. In school 1, there was a more traditional concept of teaching sports. In contrast, school 2 followed a more current concept for teaching volleyball, marked by the use of mini courts and games.

The behaviors identified as students' difficulties in the first stage were listed and quantified, initially according to the schools and then, by the total number of times they appeared along the 14 hours/class observed. Such problems gave rise to the questions featuring in the questionnaire subsequently responded to by PE teachers, including both teachers that participated in this first stage, which comprises the second stage of the study.

For the production of data, field diaries were used, in which students' behaviors were recorded throughout the game, with emphasis on their difficulties. Observations ("in loco") and records in field diaries are justified by the possibilities of the researcher's performing directly in the study, identifying the problem to be investigated to get to the results (Thomas et al., 2012).

\section{Results}

The results will be presented according to the study stages, to establish a connection between the data found. The tactical problems identified in the observations can be seen in Table 1, together with their frequency of appearance in the field diaries, first presented by schools and then by the total. There is a similarity between the difficulties presented by students from school 1 and school 2, despite the differences presented, mainly about teaching methodology used in the observer classes, therefore, the data will be presented and discussed according to the total.

\section{Classification of tactical problems}

How the intention of this study was not to compare or generalize the results, but show different realities, in addition to the two teachers from the schools observed, others were invited to participate in the study. There was no predetermined number of participants since the investigation takes place with teachers and this audience is considered difficult to access, and also because teachers are very time-pressured, busy professionals, with plenty of activities and assignments (Thuc D.C, 2017). As for the level of education of the $12 \mathrm{PE}$ teachers participating in the study, five work in the final years of elementary school, five in high school, and two at both levels. As for the education network, seven work in public schools and three in private schools.

For this stage, a questionnaire was answered by PE teachers, in which the first step was to contact public and private educational institutions in the same municipality in the An Giang province, in search of available teachers to answer the survey instrument. Among the institutions contacted, 12 PE teachers were working in the final years of elementary school and in high school, who were invited to participate in the study.

The questionnaire applied to the teachers was developed and validated by Sarruge (2018). The study tool had closed questions, on a four-point Lickert scale, ranging from never (1) to always (4), and an open question, both to identify students' difficulties during the volleyball game. The Linkert scale was adopted because of its usefulness in classifying behaviors, in the search for their frequency regarding the study problem (Thomas et al., 2012), seeking to classify them (González \& Bracht, 2012)

According to the indication of the study that developed it (Sarruge, 2018), the data were analyzed. First, the number of teachers (12) was multiplied by four, the highest score on the scale, to reach the maximum point value (40). Thus, for each problem, teachers' responses were added up to obtain the score for each tactical problem. The greater the distance from the maximum value, the greater the students' difficulty in such a situation.

Table 1. Students' difficulties in PE volleyball classes.

\begin{tabular}{|c|c|c|c|}
\hline Tactical problems & School 1 & School 2 & Total \\
\hline Setting up the attack & 15 & 8 & 23 \\
\hline $\begin{array}{c}\text { Occupying spaces } \\
\text { on the court }\end{array}$ & 10 & 7 & 17 \\
\hline $\begin{array}{c}\text { Looking for empty } \\
\text { spaces }\end{array}$ & 9 & 9 & 18 \\
\hline $\begin{array}{c}\text { Intending to contact } \\
\text { the ball }\end{array}$ & 8 & 3 & 11 \\
\hline Directing serves & 6 & 2 & 8 \\
\hline
\end{tabular}

The tactical problem identified as the most difficult for students was setting up the attack (23). The action of setting up the attack is related to making three contacts with the ball characteristic of volleyball. In the classes observed and reported in the field diaries, such action appeared as problematic mainly as students' difficulty to keep the ball in play. In these situations, the students sent the ball to the other side anyhow, that is, there was no exchange of passes to choose the best attack option and, therefore, there was no construction of moves. The second 
major difficulty identified was occupying court spaces (17). In defensive actions, it is characterized in field diaries mainly by students' little movement towards the ball when it returned to their side. Another situation that hindered students' defensive actions was their poor organization, gathering in the same space as the court or close to the line, thus leaving the middle of the court clear.

Searching for empty spaces on the court (18) was the third most frequent tactical principle. For this action, we considered students' actions related to only passing the ball to the other side, often on their backs, without looking at the target (opponent's side) or over an opponent. These actions were due to students' greatest concern to make the ball reach the other side, which often did not result in scoring, the main goal of the game.

The tactical problem intending to contact the ball was also identified (11). For this, there were the actions of exchanging passes marked mainly by students' situations to get rid of the ball, that is, they did not look for a better-positioned player to send the ball and do the next action when the attack was being built, tactical principles that are closely connected. Finally, directing serves (8), a situation similar to the tactical problem searching for empty spaces on the court, in which the students just passed the ball to the other side, without aiming to score or at least make it difficult for the opponent to receive the ball in the first action of the volleyball game. Also, in the search to identify students' difficulties in learning volleyball, in a second step, PE teachers answered a questionnaire about which tactical principles they considered most problematic in their classes. The data were used to classify these problems - stage II.
Tactical principles were classified by adding up PE teachers' responses (teacher $1=\mathrm{P} 1$ ) about each principle (Table 2). It is important to note that the principle of "searching for empty spaces on the court" was divided into two: observing the empty spaces and throwing the ball into these spaces, because, according to Borges and Diniz (2017) one needs to spot uncovered spaces in the opponent's side to then throw the ball in those spaces, characterizing the division.

In the teachers' opinion, students' greatest difficulties (highlighted in Table 2) are to direct the service and throw the ball into empty spaces. Both tactical problems have to do with how to score in volleyball. In a second level are the problems of setting up the attack, intending to contact the ball and spot empty spaces, and, lastly, occupying court spaces, a problem considered by teachers like the one that students are better able to develop during class. In addition to the classification of tactical principles, PE teachers were asked about what other difficulties they considered to be important for teaching. Five teachers considered that the technical aspects of volleyball are a problem, evidenced by the fundamentals of the sport, as can be seen in the responses of teacher 3 - "receiving any type of serve"; teacher 1 - "deficient motor gesture of the basics"; teacher 10 - "students do not have an adequate body posture"; teacher 9 - "learning to spike because of its motor complexity"; and teacher 7 - "knowing how to position the body in relation to the ball". Other difficulties were highlighted, such as students' lack of interest (teachers 2 and 5) and struggling with volleyball rules (teacher 4). Teacher 8, and 11,12 did not make any notes.

Table 2. Classification of volleyball tactical problems

\begin{tabular}{|c|c|c|c|c|c|c|c|c|c|c|c|c|c|}
\hline Tactical problem & $\mathrm{T} 1$ & $\mathrm{~T} 2$ & $\mathrm{~T} 3$ & $\mathrm{~T} 4$ & $\mathrm{~T} 5$ & T6 & $\mathrm{T} 7$ & $\mathrm{~T} 8$ & T9 & $\mathrm{T} 10$ & $\mathrm{~T} 11$ & $\mathrm{~T} 12$ & Total \\
\hline Direct the serve & 1 & 2 & 1 & 2 & 3 & 2 & 1 & 1 & 3 & 2 & 1 & 1 & 20 \\
\hline $\begin{array}{l}\text { Throw the ball in empty } \\
\text { spaces }\end{array}$ & 2 & 2 & 1 & 3 & 2 & 2 & 1 & 1 & 3 & 2 & 1 & 1 & 21 \\
\hline Setting up the attack & 2 & 2 & 2 & 2 & 2 & 2 & 2 & 2 & 2 & 2 & 2 & 2 & 24 \\
\hline $\begin{array}{l}\text { Intend to contact with the } \\
\text { ball }\end{array}$ & 1 & 2 & 2 & 2 & 2 & 2 & 3 & 2 & 2 & 2 & 2 & 2 & 24 \\
\hline Spot empty spaces & 3 & 2 & 2 & 2 & 2 & 1 & 2 & 1 & 3 & 1 & 1 & 1 & 21 \\
\hline Occupying court spaces & 2 & 2 & 2 & 2 & 2 & 2 & 3 & 3 & 3 & 3 & 3 & 3 & 30 \\
\hline
\end{tabular}




\section{Discussion}

Another principle indicated by teachers - secondly - as the difficulty is part of those named "ways to score". Sarruge (2018) indicates that teaching collective ways to score points is fundamental to volleyball lessons, precisely because it highlights the possibilities of reaching the goal of the game. The appreciation of the principles that lead to scoring a point (the main goal of volleyball) in a collective way, would bring the classes closer to the reality of the practice (Gonçalves \& Mourão, 2008).

Occupying court spaces, which came second among the greatest difficulties in the observations and as the smallest in teachers' perception are the defensive actions that guarantee the resumption of ball possession during the game (Gonçalves \& Mourão, 2008), that is, they are ways to prevent the opponent from reaching the goal of the game. Regarding defensive issues, Borges, González, Gaya, and Galatti (2017) pointed out that in an initial diagnosis made with teachers about students' difficulties, those related to defense were second to attack issues.

This view towards attack principles is also seen in collective sports coaching (Dallegrave et al., 2018), which can influence PE teachers' view of this tactical behavior, still based on the traditional model, in which actions with the ball are given priority, leaving actions without it in the background. Setting up the attack and intending to contact the ball, which scored the same in teachers' perception of students' difficulties, happen at all times in the game. Such tactical behaviors are characterized by the realization of the three contacts with the ball after the opponent's serve (side out) or in counterattacks, after the opposing team's attack. These actions are highly related to the realization of the technical fundamentals of volleyball in the best way. Fagundes and Ribas (2017) point out that all actions performed throughout the game are connected with the next action, influencing it. So, the practicing student should know the "why" of performing an overhead pass or a forearm pass in a particular position in the court, not only reproduce such moves.

These tactical principles identified as problems in the PE volleyball classes are similar to the notes in the literature on the main actions carried out during the game, namely: setting up the attack (Borges \& Diniz, 2017), ways to score the point (Hirama et al., 2015) and occupying court spaces (Pritchard et al.,2008). The tactical problems identified in the observations as students' difficulties are, mainly, setting up the attack and occupying court spaces, which differed from the main problem pointed out by teachers in their answers, which is directing serves. However, when one thinks about volleyball teaching in $\mathrm{PE}$, it is understood that the importance given to serves (way of starting the games that result in scoring) by teachers as a priority in teaching can put other tactical elements in the background, which also creates problems in this process.
The teachers' focused view of this element of the game can be explained by its relationship with the other actions of the game when thinking about coaching teams or professionals. There is evidence in women's base volleyball that a good serve favors the continuation of the game for the team itself (Cruz et al., 2018), that is, it is the first way to get closer to scoring, making the opponent's actions difficult, therefore, its importance.

Students' difficulties in learning sports at PE are still strongly related to the technical gestures of the modalities, as observed in teachers' responses about what they consider to be problems. Of the 12 study participants, five cited technical gestures as class difficulties. Borges, González, et. al. (2017) found similar information about the situations that favor the maintenance of traditional teaching models, in teachers' opinion, such as practitioners' interest and proficient knowledge of the specific motor skills required for the game to happen in the best way. This is a common situation in initial sports explorations, as teachers analyze their practices according to their experiences (Borges, Gaya, et al., 2017).

This scenario is also influenced by the few opportunities that teachers have to modify their pedagogical practice (Santos \& Nista-Piccolo, 2011) and rethink the ways of teaching in PE, just adapting to the prevailing traditional method rather than looking for "novel" ways of teaching sports (Wright et al., 2005). For Santos and Nista-Piccolo (2011), this reality occurs because the reductionist way sport is seen within the school environment by teaching sports gestures.

Teachers' view on the tactical aspects of volleyball still seems to be limited, as evidenced mainly by the belief that volleyball is a very technical sport and that this is why students' difficulties with it (Hirama et al., 2015), as well as by the small number of literature publications on the tactical problems of the sport (Fernanda et al, 2016). Borges, Gaya, et. al. (2017) report similar results of a change in perspective on the teaching of sports after carrying out an intervention that aimed to expand teachers' views, with an emphasis on understanding the game.

\section{Conclusions}

Regarding tactical principles, it was observed that those identified by the researcher as students' difficulties partially differed from teachers' perceptions. This difference can be explained by the way volleyball teaching takes place in PE classes, influenced by these professionals' initial coaching and previous knowledge about the sport in Vietnam, which points to a wide gap between academic study and the teaching practice of PE teachers.

With the main objective of diagnosing the tactical problems of volleyball in PE classes, it is clear that even with the study focus on these elements, the results showed 
that teachers' view was directed towards the technical gestures of the sport when asked about students' main difficulties in the teaching process.

To solve this problem, advances in teacher coaching in service are necessary, since the initial coaching in physical education is still outdated in this sense and teachers are offered few opportunities for continuing education, so that they can acquire knowledge about new approaches to sports teaching in PE classes.

The results of the study point out that little or no contact with current approaches to Sport Pedagogy leads teachers to responses that are based on a traditional teaching perspective. Given this scenario, it is worth thinking about the creation of coaching environments for teachers, based on the tactical principles of sports, especially for volleyball, which is usually labeled as hard to teach.

\section{REFERENCES}

[1] Alnedral, Zonifa, G., \& Yendrizal. (2020). A volleyball skills test instrument for advanced-level students. Journal of Physical Education and Sport, 20(3), 2213-2219.

[2] Aquino, R., Alves, I. S., Padilha, M. B., Garganta, J., \& Marques, R. F. R. (2017). Scientific production on the tactical-technical aspect in team sports: analysis of brazilian journals. Movimento: Revista de Educação Física Da UFRGS, 23(4), 1407-1420.

[3] Backman, E., \& Barker, D. M. (2020). Re-thinking pedagogical content knowledge for physical education teachers-implications for physical education teacher education. Physical Education and Sport Pedagogy, 0(0), 113.

[4] Barroso, A. L. R., \& Darido, S. C. (2010). School volleybal: a proposal to teaching in the dimensions concept, procedure and attitude of content. Revista Brasileira de Educação Física e Esporte, 24(2), 179-194.

[5] Belli, T., Ginciene, G., Castro, L. B., Soati, K. C., Misuta, M. S., \& Galatti, L. R. (2017). Sport Pedagogy and table tennis: new perspectives for teaching-training of the effect on late sports initiation. Pensar a Prática, 20(2), 420-429.

[6] Borges, R. M., \& Diniz, I. K. S. (2017). Volleyball. In F. J. González, S. C. Darido, \& A. A. B. Oliveira (Eds.), Esportes de Marca e com Rede Divisório ou Muro/Parede de Rebote (2a, p. 532). Editora Unijuí.

[7] Borges, R. M., Gaya, A. C. A., González, F. J., \& Galatti, L. R. (2017). Possibilities of realization of diagnosis in sports teaching: an action research with teachers of Physical Education. Motrivivência, 29(50), 104-122.

[8] Borges, R. M., González, F. J., Gaya, A. C. A., \& Galatti, L. R. (2017). Dialogues on sports teaching: continuous education through action research. Movimento, 23(3), 10251038.

[9] Cruz, P. A., Costa, Y. P., Silva, E. L. S., \& Batista, G. R.
(2018). Association between serve with defense and defense with counter-attack in female base volleyball. Revista Brasileira de Prescrição e Fisiologia Do Exercício, 12(77), 716-723.

[10] Dallegrave, E. J., Folle, A., Oliveira, V. P., \& Nascimento, J. V. (2018). Structure of practice tasks in collective sports: analysis of scientific production. Movimento, 24(3), 827842.

[11] Daólio, J. (2002). Collective sportin games: from the operational principles to the technical gestures - pendulous model according to Claude Bayer's ideas. Revista Brasileira de Ciências e Movimento, 10(4), 99-104.

[12] Fagundes, F. M., \& Ribas, J. F. M. (2017). The volleyball dinamic through the lens of motor praxiology: a praxiological analysis of setting. Revista Brasileira de Ciências e Movimento, 25(3), 134-149.

[13] Fensterseifer, P. E., Ristow, R. W., \& Borges, R. M. (2015). Basketball teaching in school physical education: na understanding of teachers analysis of the importance of tactics and the work done in class. Revista Didática Sistêmica, 17, 57-67.

[14] Fernanda et al (2016). The "Status of Art" of volleyball and the volleyball at school. Revista Brasileira de Ciências e Movimento, 24(4), 175-186.

[15] Galatti, L. R., Bettega, O. B., Paes, R. R., Reverdito, R. S., Seoane, A. M., \& Scaglia, A. J. (2017). Teaching team sports: methodological advances of strategic-tactical-technical issues. Pensar a Prática, 20(3), 639-654.

[16] Gonçalves, F., \& Mourão, P. (2008). Tactical evaluation in volleyball - defensive positioning and vulnerable zones depending on the opponents' attack zone in th 5th game of A1 final playoff. Motricidade, 4(4), 51-58.

[17] González, F. J., \& Bracht, V. (2012). Collective Sports Teaching Methodology. UFES, Núcleo de Educação Aberta e a Distância.

[18] Harvey, S., Gil-Arias, A., \& Claver, F. (2020). Effects of teaching games for understanding on tactical knowledge development in middle school physical education. Journal of Physical Education and Sport, 20(3), 1369-1379.

[19] Hirama, L. K., Joaquim, C. S., Matos, J. A. B., \& Montagner, P. C. (2015). Construction tactics in volleyball: education for understanding. Conexões: Revista Da Faculdade de Educação Física Da UNICAMP, 13(4),165-177.

[20] Lima, C. O. V., Matias, C. J. A. S., \& Greco, P. J. (2012). Tactical knowledge as a product of the combination of different teaching methods employed in inverse sequences in volleyball. Revista Brasileira de Educação Física e Esporte, 26(1), 129-147.

[21] Parente, T. A. (2020). Sport Pedagogy and volleyball: a teaching pruposal through digital didactic material. [Master's thesis - São Paulo State University, Rio Claro Bioscience Institute]. https://repositorio.unesp.br/handle/11 $449 / 192917$

[22] Pritchard, T., Hawkins, A., Wiegand, R., \& Metzler, J. N. (2008). Effects of two instructional approaches on skill development, knowledge, and game performance. Measurement in Physical Education and Exercise Science, 
12(4), 219-236.

[23] Santos, M. A. G. N., \& Nista-Piccolo, V. L. (2011). Sport and High School: the view of public school physical education teachers. Revista Brasileira de Educação Física e Esporte, 25(1), 65-78.

[24] Sarruge, C. S. L. (2018). Understanding logic in volleyball initiation: a contribution from new technologies. [Master's thesis - São Paulo State University, Rio Claro Bioscience Institute].

[25] Sgrò, F., Barca, M., Schembri, R., \& Lipoma, M. (2020). Assessing the effect of different teaching strategies on students' affective learning outcomes during volleyball lessons. Journal of Physical Education and Sport, 20(3), 2136-2142.

[26] Siedentop, D. (1994). Sport education: quality PE through positive experiences. Human Kinetics.

[27] Silva, C. L., Velozo, E. L., \& Rodrigues Júnior, J. C. (2008). Qualitative research in physical education: possibilities for knowledge building from the cultural frame of reference abstract. Educação Em Revista, 48, 37-60.

[28] Smith, B., \& Caddick, N. (2012). Qualitative methods in sport: a concise overview for guiding social scientific sport research. Asia Pacific Journal of Sport and Social Science, $1(1), 60-73$

[29] Thomás A.P, Guy Gi \& Fernanda M.I, (2020) .Volleyball in school physical education and student difficulties: analysis based on tactical principles. Journal of Physical Education and Sport, 20(5), pp 2945 - 2951.

[30] Thomas, J. R., Nelson, S. J., \& Silverman, S. J. (2012). Research Methods in Physical Activity (6th ed.). Artmed.

[31] Thuc D.C, (2017). Studying and building volleyball curriculum in optional hour at An Giang University: An Giang province. International Journal of Physical Education, Sports and Health. 4(6), pp 137-142

[32] Thuc D.C, et al, (2018). Assessing the growth about professional physical fitness and basic techniques of female volleyball students at an Giang University after a practice year. International Journal of Yoga, Physiotherapy and Physical Education. 3(4), pp 83-85.

[33] Wright, S., McNeill, M., Fry, J., \& Wang, J. (2005). Teaching teachers to play and teach games. Physical Education \& Sport Pedagogy, 10(1), 61-82. 